\title{
Pulmonalis eltérések Hodgkin-lymphomában
}

\author{
Jóna Ádám dr. - Illés Árpád dr. - Szemes Katalin oh. \\ Miltényi Zsófia dr.
}

Debreceni Egyetem, Általános Orvostudományi Kar, Belgyógyászati Intézet, Hematológiai Tanszék, Debrecen

\begin{abstract}
A Hodgkin-lymphoma kezelése a hematológia sikertörténetei közé tartozik. A korszerü kombinált kemo- és radioterápiának köszönhetően a betegek jelentős része túlél, így előtérbe kerülnek a kezelések mellékhatásai, amelyek a betegek későbbi életminőségét és élettartamát befolyásolhatják. A szerzők a Hodgkin-lymphoma tüdőben előforduló megjelenési formáit és a kezelés következtében kialakuló pulmonalis eltéréseket, szövődményeket elemzik - saját eseteik példáján. A Hodgkin-lymphoma tüdőérintettsége gyakrabban másodlagos, primer pulmonalis érintettség igen ritkán fordul elő. A szerzők saját betegeik vizsgálata során tüdőérintettséget összesen az esetek 8-12\%-ában észleltek. A kezelés rövid és hosszú távú pulmonalis mellékhatásait egyrészt az immunszuppresszióval összefüggésben lévő infekciók, másrészt a jelenleg első vonalbeli standard kezelés részét képező bleomycin, illetve a mellkasi irradiáció okozta pneumonitis és fibrosis jelentik. A Hodgkin-lymphoma pulmonalis megjelenése egyrészt diagnosztikai és differenciáldiagnosztikai nehézségeket jelenthet, stádiumot és ennek következtében kezelést módosíthat, másrészt a kialakuló mellékhatások a későbbi élettartamot és életminőséget jelentősen meghatározzák, így felismerésük döntô fontosságú. Orv. Hetil., 2016, 157(5), 163-173.
\end{abstract}

Kulcsszavak: Hodgkin-lymphoma, tüdőérintettség, bleomycin, mellkasi irradiáció, második daganat

\section{Pulmonary alterations in Hodgkin lymphoma}

Most of Hodgkin lymphoma patients survive due to combined chemo/radiotherapy. Improved survival brings longterm side effects to the front, which may determine the patients' subsequent quality of life and expected lifetime. This manuscript aims to analyze lung manifestations of Hodgkin lymphoma and treatment related pulmonary complications, demonstrated with own cases. The lung involvement in Hodgkin lymphoma is often secondary, and primary pulmonary involvement is very rare. The authors found $8-12 \%$ of lung involvement among their patients. Side effects of treatment consist of pulmonary infections in conjuction with immunosuppression, while on the other hand bleomycin and chest irradiation as part of current standard of care induced pneumonitis and fibrosis are reported. The pulmonary involvement in Hodgkin lymphoma may cause differential diagnostic difficulty. Lung involvement could modify stage and consequently treatment, and the development of side effects might determine later quality of life and expected lifetime. Therefore, identification of lung involvement is crucial.

Keywords: Hodgkin lymphoma, lung involvement, bleomycin, chest irradiation, second tumor

Jóna, Á., Illés, Á., Szemes, K., Miltényi, Zs. [Pulmonary alterations in Hodgkin lymphoma]. Orv. Hetil., 2016, 157(5), $163-173$.

(Beérkezett: 2015. november 4.; elfogadva: 2015. december 3.)

\section{Rövidítések}

ABVD = adriamycin, bleomycin, vinblastin, dacarbazin; ARDS = akut respirációs distressz szindróma; AVD = adriamycin, vincristin, dacarbazin; BEACOPP = bleomycin, etoposid, doxorubicin, cyclophosphamid, vincristin, procarbazin, prednison; $\mathrm{BEAM}=\mathrm{BCNU}$, etoposid, Ara-C, melphalan; BrECADD = brentuximab vedotin, etoposid, cyclophosphamid, doxorubi- cin, dacarbazin, dexamethason; BrECAPP = brentuximab vedotin, etoposid, cyclophosphamid, doxorubicin, procarbazin, prednison; $\mathrm{CMV}=$ cytomegalovirus; $\mathrm{CT}=$ komputertomográfia; $\mathrm{DHAP}=$ dexamethason, Ara-C, cisplatin; $\mathrm{DLCO}=$ szénmonoxid-diffúziós tüdőkapacitás; DNS = dezoxiribonukleinsav; ${ }^{18}$ FDG-PET = 18-fluorodeoxiglükóz pozitronemissziós tomográfia; FEAM = fotemustin, etoposid, Ara-C, melphalan; 
$\mathrm{HL}=$ Hodgkin-lymphoma; IF-RT = érintett mezős irradiáció; MOPP = mustárnitrogén, vincristin, procarbazin, prednison; NLPHL = nodularis lymphocyta predomináns Hodgkin-lymphoma; PD-1 = programozott sejthalál-1; R-IGEV = rituximab, ifosfamid, gemcitabin, vinorelbin; SUV = standardized uptake value

A Hodgkin-lymphomás (HL-) betegek kezelése az utóbbi évtizedek hematológiai sikertörténetei közé tartozik. A kezdetben halálos betegség jól kezelhetóvé vált a radioterápia és az egyre korszerúbb polikemoterápiák, köztük az ABVD (adriamycin, bleomycin, vinblastin, dacarbazin), valamint a nagy dózisú kezelés és autológ őssejt-transzplantáció bevezetésével [1].

Az utóbbi évtizedekben a stádiumhoz, prognosztikai rendszerekhez (rizikóadaptált kezelés) illesztett kombinált polikemoterápiával és/vagy radioterápiával történő kezelési stratégia mellett a kezelés közben a kezelésre adott korai válasz lemérésére [2] az interim 18-fluorodeoxiglükóz pozitronemissziós tomográfia/komputertomográfia $\left({ }^{18} \mathrm{FDG}-\mathrm{PET} / \mathrm{CT}\right)$ adta lehetőségeknek köszönhetően (válaszadaptált kezelés) a betegek $80-85 \%$-a komplett remisszióba kerül. Sajnos a primeren refrakter és korán relabáló betegek kezelése továbbra is kihívást jelent, számukra a nagy dózisú kezelés autológ heamopoeticus őssejt-szupportációval, valamint az újszerú, célzott terápiás lehetőségek (brentuximab vedotin, PD-1-gátlók [programozott sejthalál-1]) jelenthetnek terápiás lehetôséget $[3,4]$.

Kezdetben a kezelés célja elsősorban a túlélés növelése volt, manapság az alul- vagy túlkezelések elkerülését tartjuk fontosnak, hiszen a túlélés javulásával, a betegek gondozása során előtérbe kerültek a kezelések hosszú távú mellékhatásai, amelyek mind az életminőséget, mind a későbbi élettartamot döntően meghatározzák.

A HL pulmonalis megjelenése ritka, döntően előrehaladott betegségben találkozhatunk vele, ritkasága miatt egyrészt diagnosztikai és differenciáldiagnosztikai nehézségeket jelent, stádiumot és ennek következtében kezelést módosíthat, illetve a kezelések szövődményeként kialakuló tüdőeltérések nemcsak az életminőségre, hanem a hosszú távú túlélésre is jelentôs befolyással vannak. Mindezek miatt felismerésük, ismeretük döntő jelentőséggel bír a korszerú személyreszabott kezelésekben és a betegek követése/gondozása során is [5-7].

A HL tüdőmanifesztációinak formáiról, a kezelések korai és késői pulmonalis szövődményeiről ritkábban esik szó közleményekben, saját tapasztalatainkat felhasználva ezt kívántuk áttekinteni.

\section{Hodgkin-lymphoma pulmonalis érintettséggel}

A HL-ben extranodalis manifesztáció a betegek 15-30\%ánál fordul elő. A tüdő érintettsége HL-ben viszonylag ritka, az esetek 8-12\%-át [8] jelenti, és általában hilaris vagy mediastinalis nyirokcsomó-betegséghez társul. Nyirokcsomó-érintettség nélküli pulmonalis manifesztáció legtöbbször relapsusok vagy progresszió és disszemináció alkalmával fordul elő. A tünetek sokszor jellegtelenek. Jelentkezhet gyengeség, láz, éjszakai izzadás, nehézlégzés vagy fulladás, köhögés, köpetürítés, mellkasi fájdalom, esetleg haemoptoe.

A primer pulmonalis HL (PPHL) igen ritka, az irodalomban kevesebb mint 100 esetet közöltek. A HL tüdőérintettsége gyakrabban másodlagos. Leggyakrabban hilaris nyirokcsomóból kiinduló, a szomszédos tüdőparenchymára terjedő folyamat képében jelenik meg, vagy nodularis formában (általában perifériásan, elmosódott határral). A nodulusok járhatnak üregképződéssel, lehetnek szoliterek, illetve multinodularisak. Ritkábban a nyirokutak mentén, mint interstitialis infiltráció észlelhetünk pulmonalis HL-t [9-11].

Sokszor nemcsak a tünetek szegényesek, hanem a hagyományos diagnosztikai módszerek sem tudják egyértelműen igazolni a tüdő érintettségét. A hagyományos CT-vel készült képeken az extranodalis érintettség gyakran nehezen kivehetô vagy nem is ábrázolódik. A diagnózisban nagy segítséget nyújt(hat) a tumoranyagcserét megjeleníto" ${ }^{18} \mathrm{FDG}$-PET, amelynek felvételein olyan laesiók is azonosíthatóak, amelyeket a CT-felvételek nem mutattak ki. A primer staging céljából végzett ${ }^{18} \mathrm{FDG}-$ PET/CT felvételeken a megnövekedett ${ }^{18} \mathrm{FDG}$-felvétel utalhat jóindulatú folyamatra (például granulomatosus betegségre), ritkábban azonban pulmonalis érintettséget jelez. A kezelés után készült ${ }^{18} \mathrm{FDG}$-PET/CT vizsgálat során megnövekedett ${ }^{18} \mathrm{FDG}$-felvételt okozhat pneumonia, kemo-, illetve sugárterápia okozta pneumonitis, opportunista fertőzések és tüdőgyulladáshoz kapcsolódó bronchiolitis obliterans. Lymphoma valószínúsíthetô, ha korábban kezelésben nem részesülő betegnél új nodulusok jelennek meg, amelyek mérete nagyobb, mint 1,5 $\mathrm{cm}$, illetve ha ${ }^{18} \mathrm{FDG}$-felvételük meghaladja a mediastinalis vérpool aktivitását. Endobronchialis betegség esetén a kóreredet tisztázásában segítséget nyújthat a köpet és a bronchoalveloaris lavage citopatológiai vizsgálata, illetve a bronchofiberoszkópia. A diagnózis megállapításához szükséges szövettani mintavétel történhet transthoracalis túbiopsziával, videoasszisztált torakoszkópos lobectomiával. A legmegbízhatóbb eredményt azonban a nyílt tüdóbiopszia adja $[12,13]$.

\section{Primer pulmonalis érintettség}

A primer PPHL diagnózisának felállításához a következő kritériumoknak kell teljesülniük: 1. a folyamat a tüdőre korlátozódik a hilusi nyirokcsomók minimális érintettségével vagy a nélkül; 2 . a szövettani eredmények megfelelnek a HL diagnózisának; 3 . kizárható az extrathoracalis lymphoma jelenléte, illetve a mediastinalis nyirokcsomókról átterjedő folyamat. Diagnosztikája nem könnyú, gyakorta csak nyílt sebészeti mintavétel vezet eredményre, és éppen ezért sokszor hosszú idő telik el a betegség 
felismeréséig és kezeléséig [13, 14]. Saját, korábban közölt esetünkben láz és a jobb felső lebenyben észlelt infiltráció hátterében infekció irányú kivizsgálás, ismételt CT-vezérelt transthoracalis túbiopszia, majd nyílt sebészi feltárás során intraoperatív szövettan sem vezetett eredményre, csak a később elvégzett pulmonectomia adott definitív szövettani diagnózist.

\section{Másodlagos tüdöérintettséggel járó $H L$}

A változatos megjelenés és a nem specifikus kép differenciáldiagnosztikai nehézséget jelenthet $[10,13,15]$ (1. táblázat). A következőkben a különböző morfológiai megjelenési formákra hozunk egy-egy esetet saját betegeink közül.

\section{Cavitalis laesio}

Cavitalis laesio esetén felmerülhet többek között tüdőabscessus, Wegener-granulomatosis, metasztázis, gombafertőzés. Betegünk - az 1988-ban született nő kivizsgálása száraz köhögés miatt kezdődött, konvencionális képalkotó vizsgálatok történtek, melyek során a jobb tüdőben a hilussal összefüggő infiltrátum mutatkozott. Bronchoszkópia, majd ismételt transthoracalis túbiopszia sem vezetett eredményre. Mediastinoscopia nodularis sclerosis altípusú klasszikus HL-t igazolt. Stádiummegállapító PET/CT-n leírt supradiaphragmaticus bulky tumorból kiemelendő a jobb tüdő középső lebenyében $6 \times 10 \mathrm{~cm}$-es centrálisan nagy necroticus területet tartalmazó, egyebekben intenzíven dúsító lágyrészterime, amely széles alappal a fali és mediastinalis pleurával összefekszik. A betegség II/BEX-nek volt tartható, amely miatt 6 ciklus ABVD-kezelésben és a mediastinum területére érintett mezős irradiációban részesült, amelynek hatására az interim PET/CT-n jelentős morfometabolikus regresszió mutatkozott, a tüdőben lévő terime 2,4×2,7 cm-re csökkent. Restaging PET/CT-n komplett metabolikus remisszió került leírásra, de a JS5-ben még aktív köteg mutatkozott, ennek hátterében az irradiáció hatása is felmerült. Későbbi kontrollon ennek metabolikus aktivitása csökkent, morfológiailag nem változott (1. A ábra).

\section{Pulmonalis infiltrátum}

A pulmonalis infiltrátum felvetheti atípusos pneumonia, tüdőtuberculosis vagy más malignus folyamat lehetőségét. Betegünk, az 1956-os születésű férfi kivizsgálása nyaki lymphadenomegalia miatt kezdődött 2013 júniusában, amelynek biopsziája nodularis sclerosis altípusú klasszikus HL-t igazolt. Stádiummegállapító PET/CT supradiaphragmaticus nodalis érintettséget, valamint a tüdő jobb felső lebenyének bázisán, lateralisan egy $22 \times 22$ mm-es, a JS9-ben és a JS3-ban egy-egy $13 \mathrm{~mm}$-es metabolikusan aktív gócos infiltrátumot igazolt. Mindezek alapján a betegség IV/AE stádiumúnak volt tartható. Klinikai vizsgálat keretében 6 ciklus brentuximab vedotin + AVD (adriamycin, vincristin, dacar-
1. táblázat $\mid$ A Hodgkin-lymphoma pulmonalis megjelenési formái és differenciáldiagnózisuk

\begin{tabular}{|c|c|c|}
\hline $\begin{array}{l}\text { Megjelenési } \\
\text { forma }\end{array}$ & \multicolumn{2}{|c|}{ Differenciáldiagnózis } \\
\hline $\begin{array}{l}\text { Pulmonalis } \\
\text { infiltrátum }\end{array}$ & \multicolumn{2}{|l|}{$\begin{array}{l}\text { Atípusos pneumonia } \\
\text { Tüdőtuberculosis } \\
\text { Malignus folyamat } \\
\text { Wegener-granulomatosis } \\
\text { Kötőszöveti betegség } \\
\text { Eosinophil pneumonitis } \\
\text { Gyógyszertoxicitás }\end{array}$} \\
\hline $\begin{array}{l}\text { Cavitalis } \\
\text { laesio }\end{array}$ & \multicolumn{2}{|c|}{$\begin{array}{l}\text { Tüdőabscessus } \\
\text { Tüdőtuberculosis } \\
\text { Primer tüdőcarcinoma } \\
\text { Tüdőmetasztázis } \\
\text { Gombafertőzés } \\
\text { Hydatid cysta } \\
\text { Necroticus pneumonia } \\
\text { Pneumoconiosis } \\
\text { Tüdőinfarktus } \\
\text { Wegener-granulomatosis } \\
\text { Bronchialis cysta } \\
\text { Rheumatoid tüdőbetegség } \\
\text { Intralobaris pulmonalis szekvesztráció } \\
\text { Terápiát követő Hodgkin-lymphoma }\end{array}$} \\
\hline Nodulus & $\begin{array}{l}\text { Fibrosis } \\
\text { Tüdőabscessus } \\
\text { Tüdőgyulladás } \\
\text { Atelectasia } \\
\text { Bronchogen cysta } \\
\text { Gyógyult tüdőinfarktus }\end{array}$ & \begin{tabular}{l}
\multicolumn{1}{c}{ Malignus } \\
Adenocarcinoma \\
Squamosus sejtes \\
carcinoma \\
Metasztázis \\
Differenciálatlan nem-kis \\
sejtes carcinoma \\
Kis sejtes tüdőrák \\
Bronchoalveolaris sejtes \\
carcinoma \\
Nagy sejtes tüdórák \\
Carcinoid tumorok \\
Lymphoma \\
Adenosquamosus \\
carcinoma \\
Adenoid cystás carcinoma \\
Teratoma
\end{tabular} \\
\hline
\end{tabular}

basin) kezelést kapott, amelynek hatására az interim PET/CT-n Deauville 1 , restaging PET/CT-n pedig komplett metabolikus remisszió mutatkozott (1. B ábra). 

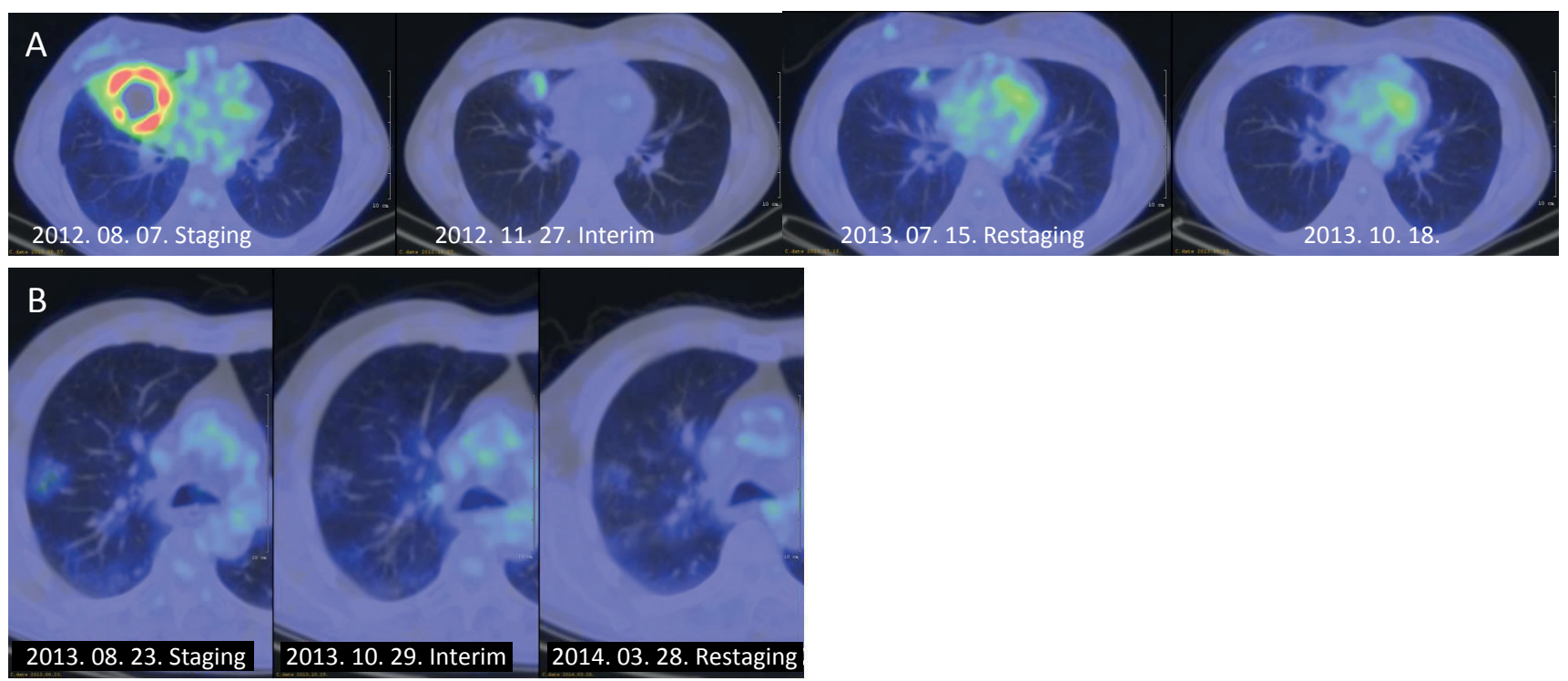

1. ábra $\quad$ A) Cavitalis laesio. II/BEX stádium, 6× ABVD + IF-RT, komplett metabolikus remisszió. B) Infiltrátum, IV/AE stádium 6× A + AVD kezelés, komplett metabolikus remisszió

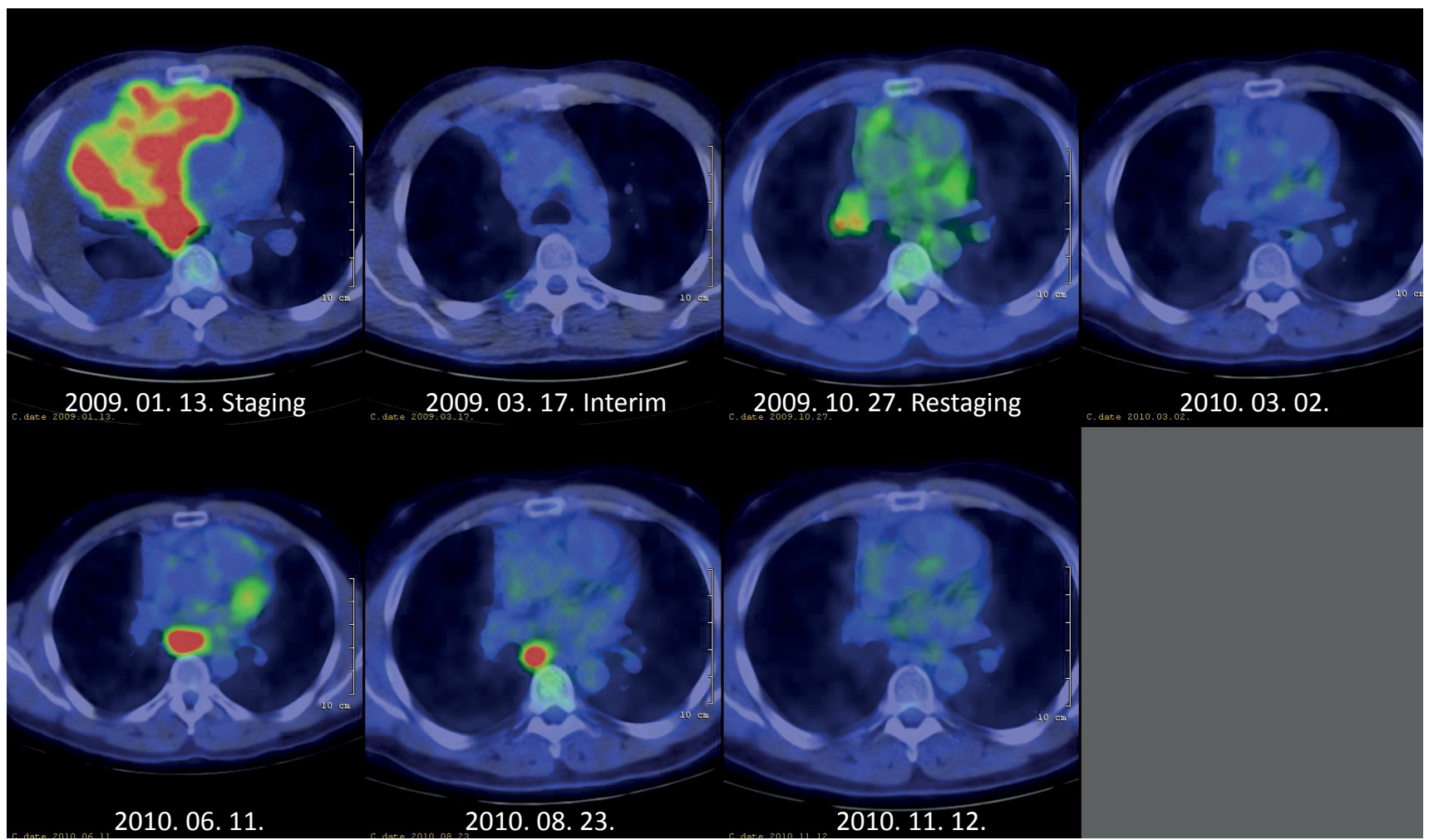

2. ábra

Ráterjedéses extranodalis tüdóérintettség. II/BXE stádium, 6× ABVD + IF-RT, relapsus miatt $4 \times$ DHAP, őssejtgyüjtés, majd autológ Tx, utána konszolidáló $16 \times$ brentuximab vedotin vs. placebo, jelenleg remisszióban

Ráterjedéses extranodalis (hilaris nyirokcsomóból tüdőparenchymára terjedés)

Az 1974-ben született férfi 2008. októberben jelentkezett szakrendelésen. Rutin mellkasröntgenen mediastinalis térfoglalás, majd mediastinoscopia során kevert sejtes klasszikus HL igazolódott. Stádiummegállapító PET/CT az elülső mediastinumban a rekeszig követhető, $18 \times 9 \times 13 \mathrm{~cm}$-es pleurától el nem választható, radio- farmakont inhomogénen halmozó térfoglalást igazolt, amely a jobb oldali foóhörgóket szúkítette, a jobb alsó lebeny atelectasiás volt. Stádiuma ezek alapján II/BXE volt, amely miatt 6 ciklus ABVD-kezelést és a mediastinum területére érintett mezős irradiációban részesült. Restaging PET/CT komplett remissziót igazolt, azonban egy éven belül korai relapsus igazolódott, amely miatt terápiaintenzifikálás, autológ őssejt-transzplantáció 


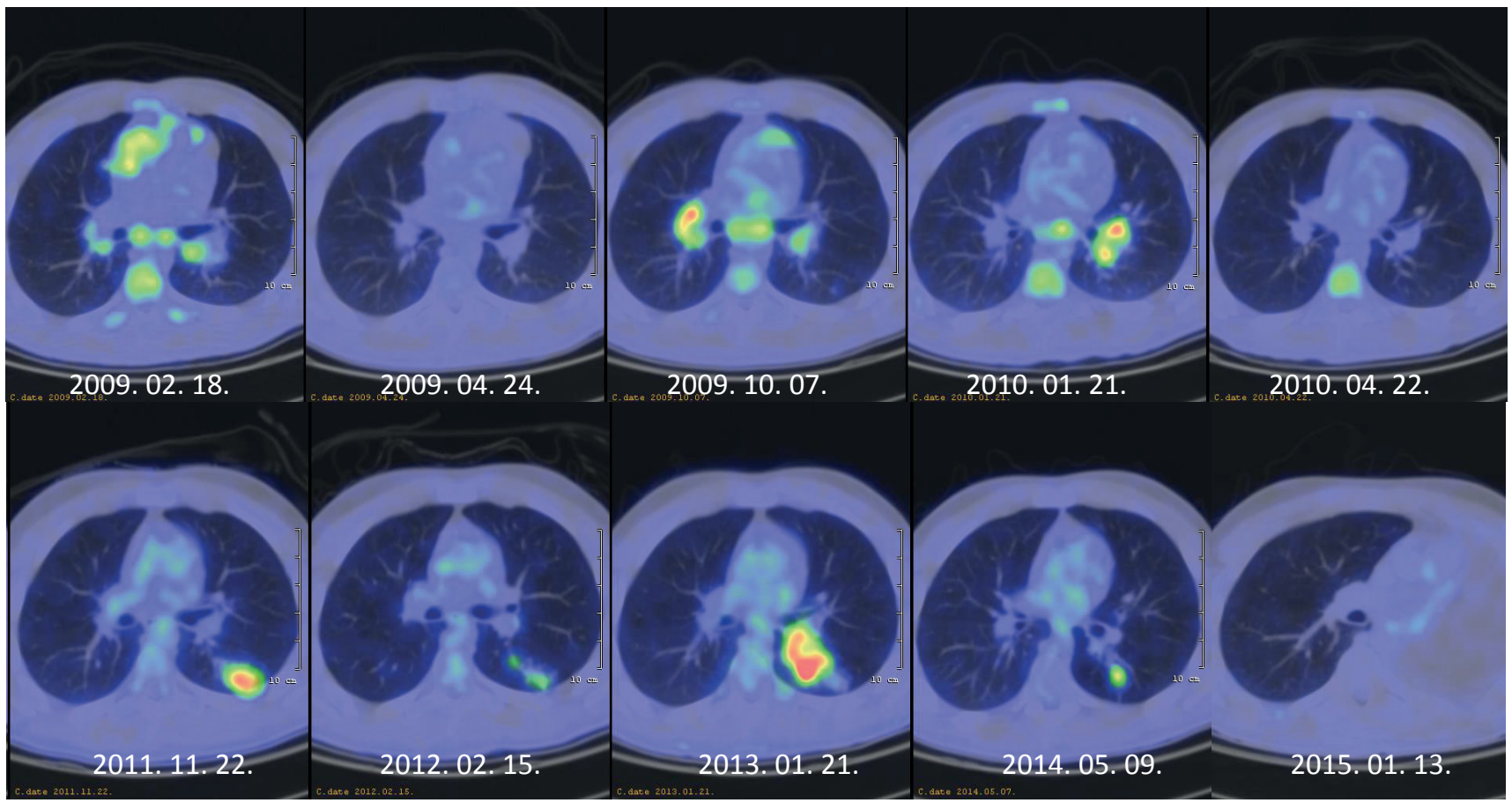

3. ábra $\mid$ Szekunder pulmonalis (nodularis) érintettség. IV/BE stádium, $6 \times \mathrm{ABVD}, 3 \times \mathrm{DHAP}$, majd további progresszió miatt $2 \times \mathrm{R}-\mathrm{IGEV}+\mathrm{bortezomib,}$ IF-RT, debulking: bendamustin + doxorubicin, majd autológ Tx, utána konszolidáló $16 \times$ brentuximab vedotin vs. placebo, majd progresszió miatt újabb $16 \times$ brentuximab vedotin

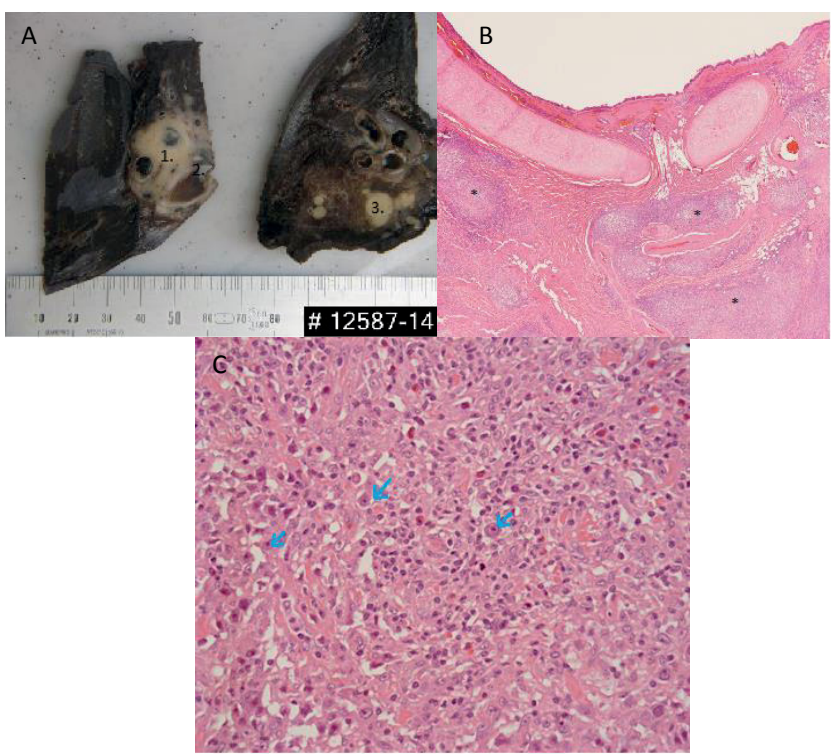

4. ábra

\begin{abstract}
A) A tumor (1.) makroszkóposan eléri a hörgőt (2.), a bronchusokban gyulladásos exsudatum (3.). B) A hörgő falának környezetében nodularis mintázatot mutató tumor ${ }^{*}$ ). C) Nagymére tü atípusos Hodgkin-sejtek $(\leftarrow)$ és reaktív sejtek. A kóros sejtekben prominens nucleolus
\end{abstract}

történt, majd brentuximab vedotin fenntartó kezelésben részesült, azóta komplett remisszióban van (2. ábra).

\section{Nodularis megjelenésü tüdő-HL}

Nodularis kép mögött állhat granulomatosus infekció, fibrosis, hamartoma, haemangioma, arteriovenosus mal- formatio, adenocarcinoma. Betegünk, az 1990-es születésű férfi kivizsgálása 2009 januárjában kezdődött fulladás, fogyás és láz miatt. A stádiummegállapító vizsgálatok során IV/BE stádiumú nodularis sclerosis altípusú klaszszikus HL igazolódott, a jobb csípólapát és a tüdő multiplex (nodularis) érintettségével. Összesen 6 ciklus ABVD-kezelést, majd progresszió miatt további 3 ciklus DHAP-kezelést kapott. Részleges, kevert válasz miatt 2010. márciustól 2 ciklus R-IGEV protokollt (rituximab, ifosfamid, gemcitamin, vinorelbin) és bortezomibot kapott. 2010 júniusában érintett mezős irradiációban részesült a mediastinum, a nyak és a tüdő régiójára. A sugárterápiát követôen is észlelhető nyaki residuumok miatt „debulking”-ként bendamustin + doxorubicint kapott, majd autológ transzplantáció történt 2010 augusztusában. 2013 márciusában a bal tüdőben lévő terime fokozatos növekedését észlelték, majd transbronchialis mintavétel során újabb relapsusa igazolódott. Emiatt brentuximab vedotin kezelésben részesült. 2014 májusában készült PET/CT-n részleges metabolikus és morfológiai regresszió mellett a bal tüdőben egy szabálytalan alakú, $27 \times 10 \mathrm{~mm}$ legnagyobb kiterjedésú és egy $1 \times 1 \mathrm{~cm}$ nagyságú területen intenzíven halmozó lágyrész-képlet volt látható (3. ábra). 2014 júliusában a hilussal összefüggő centrálisabb gócok volumene nőtt, morfometabolikus progressziót véleményeztünk. Végül 2014 novemberében pulmonectomiára került sor, amely az alapbetegséget igazolta. A tumor makroszkóposan elérte a hörgót, illetve gyulladásos exsudatum töltötte ki a bronchusokat (4. ábra). A mútétet követően készült 
kontroll PET/CT 2015. januárban kóros ${ }^{18}$ FDG-halmozást nem mutatott, komplett metabolikus remisszió volt észlelhető.

\section{Pleuralis effúzió}

Az 1974-ben született nő kivizsgálása 2014 áprilisában kezdődött gyengeség, fogyás, hőemelkedés, fulladás miatt. A mellkas-CT mediastinalis lymphadenomegaliát és pericardialis folyadékgyülemet írt le. 2014 májusában a Szívsebészeti Klinikán pericardialis folyadék fenesztrációja történt. A bal oldali nyaki nyirokcsomó biopsziája kevert sejtes altípusú klasszikus HL-t igazolt. A 2014 júniusában végzett stádiummegállapító PET/CT vizsgálat során mediastinalis bulky tumor, supradiaphragmaticus nodalis érintettség, jobb oldali aktív pleuralis folyadékgyülem került leírásra. Mindezek alapján a betegség stádiuma IV/BE. Hat ciklus ABVD-kezelést kapott 2014. novemberig. A 2014. decemberben elvégzett restaging PET/CT vizsgálat komplett metabolikus remissziót igazolt (5. ábra).

\section{A kezelések pulmonalis szövődményei}

A HL-betegek kezelése során alkalmazott kezelési modalitások közül a jelenleg első vonalban használatos ABVD részeként alkalmazott bleomycin okozta tüdőkárosodás és a mellkast érintő sugárkezelés okozta irradiációs pneumonitis és fibrosis észlelhető leggyakrabban. A kezelések késői szövődményeként tüdődaganat kialakulására is számítani lehet, illetve mind a betegség, mind a kezelések okozta immunszuppresszív állapot miatt infekciók is elöfordulhatnak [16].

\section{Gyógyszer okozta tüdőkárosodások}

\section{Bleomycin}

\section{Akut károsodás}

A bleomycin indukálta tüdőkárosodás a hiperszenzitív pneumonitis és obliteratív bronchiolitistől az akut interstitialis pneumoniáig és progresszív tüdőfibrosisig terjed. Toxikus hatása a szabadgyök-keltő képességének, míg a tüdőspecifikus tulajdonsága a deaktiváló enzim - a bleomycinkatalizáló hidroláz - tüdőben való hiányának tulajdonítható [17].

A tünetek nem specifikusak, gyakori a hirtelen kezdet, a köhögés és a pleuralis fájdalom. Mellkas-röntgenfelvé- telen kétoldali interstitialis és alveolaris infiltrátum jelentkezhet, döntően az alsó tüdőmezőkben, a borda-rekesz szögletnél.

A tüdőkárosodás megítélésére a korai stádiumban szén-monoxid-diffúziós tüdőkapacitás (DLCO) -vizsgálatot javasolnak, a kezelés előtti eredményhez viszonyított több mint 40\%-os csökkenés fel kell hogy hívja a figyelmet a bleomycin okozta tüdőkárosodásra. Spirometriás vizsgálat alapján - a restriktív légzészavarnak megfelelően - a statikus paraméterek csökkenése tapasztalható. Akut szövődmény esetén a bleomycin elhagyását és iv. szteroidkezelést javasolnak. A bleomycin szokásos dózisa $10 \mathrm{mg} / \mathrm{m}^{2}$ intravénásan vagy intramuscularisan. Tanszékünkön döntően intramuscularisan alkalmazzuk a bleomycint és a dózist $15 \mathrm{mg}$-ban maximalizáljuk. A bleomycin fél életideje nagyságrendileg egyezik intravénás és intramuscularis alkalmazás esetén. A csúcskoncentrációt azonban csak az intravénás tizedének találták intramuscularis alkalmazás esetén [18], ezzel hozzuk összefüggésbe azt, hogy eseteinket áttekintve mindössze egy akut pneumonitisszel találkoztunk, amelyet bleomycintoxicitásnak tartottunk, így az utolsó (6.) ciklus A(B) VD-t bleomycin nélkül kapta meg a beteg, és az akut szakban $1 \mathrm{mg} / \mathrm{ttkg}$ dózisban methylprednisolont alkalmaztunk a tünetek enyhüléséig. Egy esetben az imatinib kedvező hatásáról számoltak be [19].

Több esetet közöltek, amelyben a ${ }^{18}$ FDG-PET/CT hasznos diagnosztikus eszköznek bizonyult a bleomycin indukálta tüdőkárosodás korai felismerésében [20, 21]. A légzésfunkciós vizsgálatok és a konvencionális CTvizsgálat nem képes azonosítani a bleomycin indukálta gyulladás metabolikus aktivitását, viszont a ${ }^{18} \mathrm{FDG}-\mathrm{PET} /$ CT a metabolikus eltérések azonosítására is alkalmas, így lehetőséget teremt az aktív gyulladás és a residualis roncsolás megkülönböztetésére. A szerzők így dönthettek a kezelés időbeni megkezdéséról, hiszen az csak a gyulladásos fázisban hatékony, a fibroticus fázisban már nem.

A brentuximab vedotin (anti-CD30 antitest és monomethyl aurostatin E konjugátuma) első vonalbeli ABVDvel való kombinációban történő vizsgálata közben derült fény a bleomycinnel való additív tüdőkárosító hatásra, így az csak AVD (adriamycin, vincristin, dacarbazin) kemoterápiával kombinációban ajánlható [22]. A Német Hodgkin Lymphoma Munkacsoport (GHSG) vizsgálja a brentuximab vedotin lehetséges helyét az eszkalált BEACOPP-protokoll (bleomycin, etoposid, doxorubi-

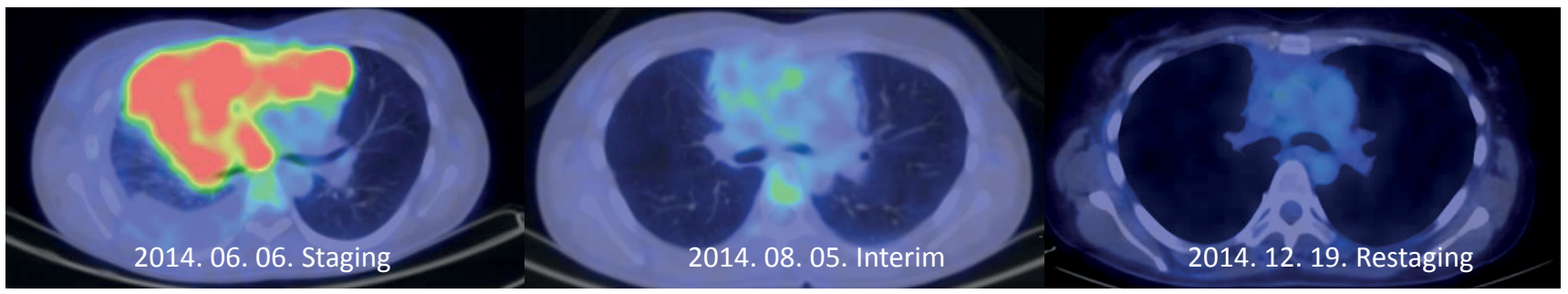

5. ábra $\quad$ Pleuralis effúzió. IV/BE stádium, $2 \times$ ABVD után interim PET/CT, jó terápiás válasz, Deauville 1, összesen 6 ciklus ABVD után komplett metabolikus remisszió észlelhető 
cin, cyclophosphamid, vincristin, procarbazin és prednison) átalakításával két kísérleti variáns formájában: BrECAPP (brentuximab vedotin, etoposid, cyclophosphamid, doxorubicin, procarbazin, prednison) és BrECADD (brentuximab vedotin, etoposid, cyclophosphamid, doxorubicin, dacarbazin, dexamethason) [23].

A gemcitabin önállóan vagy kombinációban való alkalmazásáról (cisplatinnal, vinorelbinnel, vinorelbinnel és ifosfamiddal, rituximabbal, transzplantációs kondicionáló kezelésként, őssejt-mobilizáló kezelésként) is kedvező mellékhatásprofilról és akár 70\%-ot elérő válaszarányról számoltak be a refrakter/relabáló HL-betegek kezelése során [24]. Bleomycinnel együtt alkalmazva azonban az első vonalbeli ABVD-protokoll módosításaként ABVG-t (doxorubicin, bleomycin, vinblastin és gemcitabin) adva a kezelt betegek $42 \%$-ánál jelentkezett akut pulmonalis toxicitás [25]. Hasonlóképpen, a BEACOPP módosítása BAGCOPP-ként (bleomycin, etoposid, gemcitabin, cyclophosphamid, vincristin, procarbazin és prednison) a betegek 30\%-ában okoz tüdőkárosodást, zömmel 3 ciklus kezelés után [26]. Egy következő tanulmányban az anti-CD-30 antitest SGN-30-at GVD-protokollal (gemcitabin, vinorelbin, doxorubicin) kombinálva észleltek az esetek 7\%-ában pulmonalis toxicitást. Az esetek zömében az Fc $\gamma$ RIIIa gén V/F genotípusát észlelték, amelynek az antitestdependens celluláris citotoxicitás kialakításában játszott szerepe révén monoklonális antitestekre adott válaszban van szerepe, amit így független rizikótényezőnek tartottak pulmonalis toxicitás kialakulására [27]. A carmustin- (BCNU-) tartalmú protokollok szintén potenciálisan tüdőkárosító hatásúak lehetnek [28]. Az olasz munkacsoport ezért ennek fotemustinra való cseréjét javasolja a többszörös pulmonalis rizikófaktorokkal rendelkező betegek kondicionáló kezelése során (BEAM-FEAM) [29].

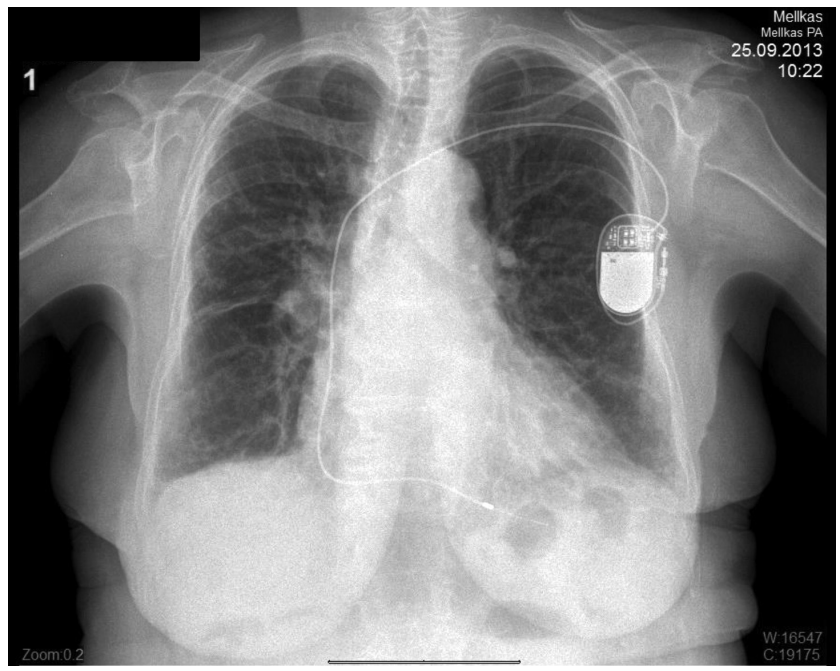

6. ábra

Diffúz fibrosis képe idős HL-beteg (megelőző kezelés: $2 \times$ ABVD $+4 \times$ EBVD + IF-RT a mediastinumra) gondozása során készített rutin mellkasröntgenen. Légzésfunkciós vizsgálat enyhe fokú perifériás exspirációs légúti obstrukciót mutatott. Bleomycin hidraláz gén vizsgálata során a mutált génre homozygota volt

\section{Késôi károsodás}

Az irodalmi adatok szerint hosszú távú tüdőkárosodás a bleomycinkezelt betegek 20-46\%-ában figyelhető meg, a mortalitási ráta $1-3 \%$ [30]. Klasszikusan a bleomycin által okozott interstitialis fibrosis radiológiai jellemzője a bibasilaris reticularis rajzolatfokozódás vagy a finom nodularis infiltrátumok. A bleomycin indukálta tüdőkárosodás során szabadgyök-képzôdés, majd dezoxiribonukleinsav- (DNS-) károsodás, pneumocyta- és endothelsejt-károsodás, kóros citokinkaszkád-képződés, gyulladás, fibroblastaktiváció, fibrosus kicsapódás, fibrinképződés és végül interstitialis tüdőfibrosis figyelhető meg. A tüdőkárosodásra hajlamosító faktorok között szerepel a kumulatív dózis, kor, beszúkült vesefunkció, dohányzás és az alkalmazás módja (intravénás vagy intramuscularis) (6. ábra). A kolóniastimuláló faktorok és a mellkasi irradiáció additív hatása vitatott [31-33].

\section{Mellkast érintô irradiáció}

\section{Korai szövődmények}

A mellkast érintő irradiáció tüdőkárosító hatása jól ismert, azelőtt talán a leggyakoribb oka volt a tüdőtoxicitásnak. Az irradiációs pneumonitis jellegzetesen a sugárzás után 1-3 hónappal is jelentkezhet, kialakulásának gyakorisága és súlyossága függ az irradiáció típusától, a besugárzott tüdőterület nagyságától és az egyszerre leadott napi és összdózistól [34]. Tünetként száraz köhögés, láz és fulladás jelentkezhet. Az irradiált tüdőterületnek megfelelően infiltrátum észlelhető a mellkasröntgenfelvételen, amelynek kialakulása az alveolaris pneumocyták átmeneti károsodásának és exsudatumképződésnek köszönhető. Ritkán pleuralis effúzió és megvastagodás is kialakulhat. A radiációs pneumonitis kezelése enyhe esetben köhögéscsillapító, nem szteroid gyulladásgátlók, középsúlyos esetben pedig nagy dózisú szteroid adását jelenti. Bár a szteroid alkalmazása csökkenti az akut tüdőkárosodás mértékét, a progresszív fibrosis kialakulását nem akadályozza meg [35].

\section{Késői szövődmények}

A tényleges fibrosis a besugárzás után 6 hónappal jelentkezhet. Kialakulásának valószínűsége elsősorban a besugárzott terület nagyságától és a teljes dózistól függ, az egyszerre leadott napi dózis kevésbé számít. Kialakulása az alveolusok falát alkotó kötőszövet kiterjedt proliferációjának, hialinizációnak és érfal-megvastagodásnak köszönhető. Nem találtak egyértelmú összefüggést az akut pneumonitis jelentkezése és a fibrosis későbbi kialakulása között. A régi fibrosis területén spontán pneumothorax is kialakulhat. A már ténylegesen kialakult fibrosis, sajnos, irreverzibilis, így kezelésére nincs mód. Mantle irradiáció után - az irradiált területnek megfelelően - a fibrosis elsősorban a tüdőcsúcsokat és a mediastinum területét érintheti (7. ábra). A vitálkapacitás körülbelül $10 \%$-kal csökkent az irradiáció után egy hónappal, és három hónappal később sem romlott tovább. Diffúziós kapacitásbeli vál- 


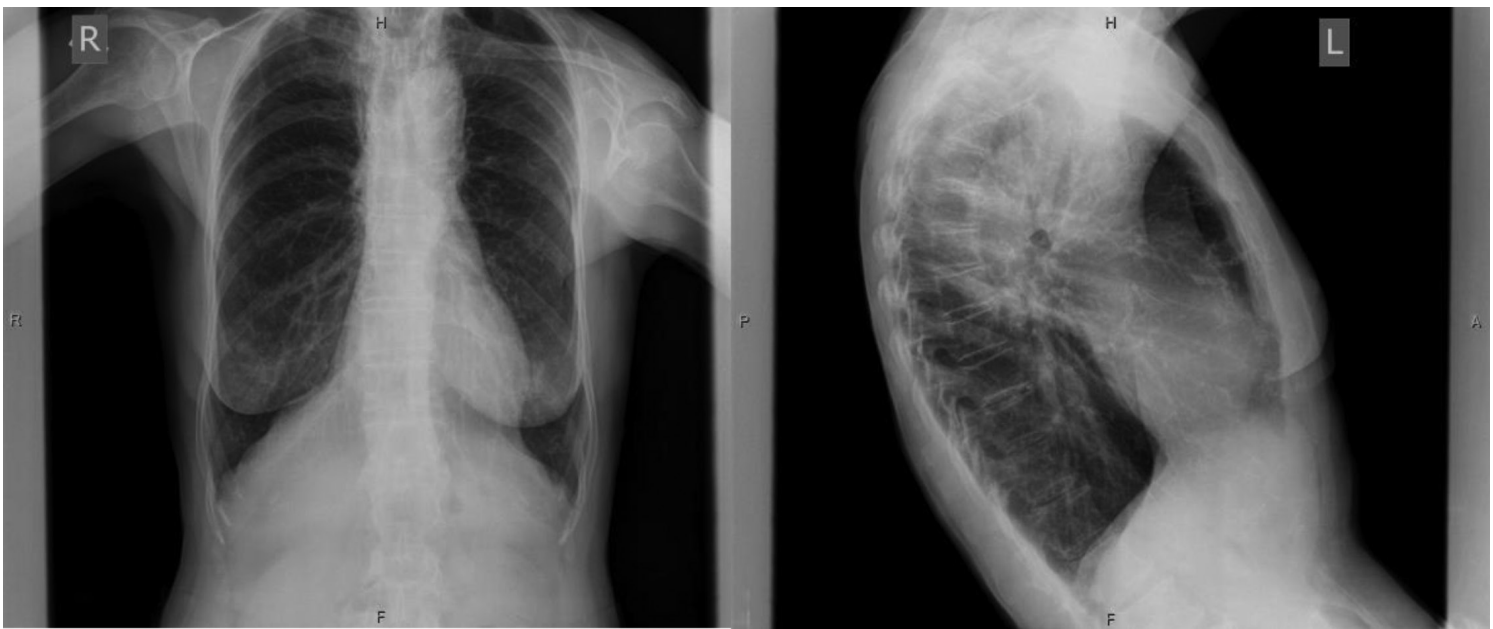

7. ábra

Posztirradiációs fibrosis képe középkorú HL-beteg (kezelés: mantle irradiáció, későbbiekben relapsus miatt $6 \times$ ABVD) rutin mellkasfelvételén mindkét oldalon, a csúcsban és dorsalisan, az arcus alatt. Légzésfunkciós vizsgálata kisfokú restriktív ventilációs zavart mutatott. Bleomycin hidraláz gén vizsgálata során a vad génre homozygotának bizonyult

tozást nem tapasztaltak [35]. Azon betegeknél kell romló tüdőkárosodásra számítani, akik kiterjedtebb területen, nagyobb dózisban szorulnak irradiációra a mediastinum, a hilusok vagy a tüdők érintettsége miatt. Manapság már a kombinált kezelések miatt csak az I/A stádiumú NLPHL-betegeket kezeljük önmagában irradiációval [16], és a sugárzás által érintett terület is kisebb (érintett mezős irradiáció, IF-RT). Más irodalmi adatok szerint is a mellkast érintő irradiáció nem járul hozzá szignifikánsan a bleomycin tüdőkárosító hatásához, de a reverzibilis károsodás időtartamát megnyújtja [36].

\section{Pulmonalis infekciók}

A betegség, valamint a kezelések immunszuppresszív hatása következtében a fertőzések fokozott kockázatával kell számolnunk. A T-, B-lymphocyták, a lép és a polimorfonukleáris leukocytasejtek funkciójának zavara eredményezi azt az immunszupprimált állapotot, amely egybeesik a betegség kezdetével, progresszió esetén súlyosbodik, a kemoterápia és/vagy irradiáció pedig tovább rontja. A standard $\mathrm{ABVD}$ lázas neutropeniát eredményező hatása 5-10\% között van, így primer kolóniastimuláló profilaxis nem indokolt. Amennyiben ezt a rizikót egyéb tényezők $20 \%$ fölé emelik, úgy a kolóniastimuláló profilaxis alkalmazása indokolt. Neutropenia esetén dóziscsökkentés, a kezelés halasztása vagy kolóniastimuláló faktor alkalmazása, valamint antibiotikum alkalmazása lehet indokolt [37]. A gyakoribb bakteriális fertőzések mellett egyre gyakoribbak a fungális és virális fertőzések is. Bakteriális kórokozók leggyakrabban: Klebsiella pneumoniae, Staphylococcus aureus, Pseudomonas aeruginosa és Escherichia coli. Tekintettel arra, hogy a HL-betegek súlyosan CD4+ T-sejt-depletáltak lehetnek már a kezelés előtt, pulmonalis fertőzés esetén mindig gondoljunk Pneumocystis jiroveci-infekció lehetőségére is [38]. Gombainfekciót Cryptococcus, Histoplasma és Coccidioides fajok okozhatnak. Candida vagy Aspergillus fajok a már előzetesen a kemoterápia által immunszupprimált esetekben fordulnak elő gyakrabban. Leggyakoribb virális patogének között szerepel a cytomegalovirus, herpes simplex vagy varicella zoster vírus. Leggyakrabban pneumonia (37-57\%) vagy bacteraemia (25-33\%) alakulhat ki [39]. A lázas neutropenia kezelése szokásos módon történik: mikrobiológiai minták tenyésztésre való elküldésével és empirikus széles spektrumú antibiotikum adásával. Tartósan fennálló láz esetén invazív gombainfekció lehetősége merül fel [40]. A pneumonia ritka, de súlyos esetben akut respirációs distressz szindrómává (ARDS) alakulhat (8. ábra), amely invazív légzéstámogatás szükségessége esetén igen rossz prognózissal bír [41].

\section{Szekunder bronchuscarcinoma}

Ismert a HL-betegek szekunder malignitásokra való nagyobb hajlama [42]. Akut myeloid leukaemia, nonHodgkin-lymphoma mellett szolid daganatok rizikója is emelkedett (emlő, tüdő, pajzsmirigy, gyomor, vastagbél, hasnyálmirigy, vese, melanoma). Irodalmi adatok szerint mind a tüdőt érintő irradiáció, mind a kemoterápiás kezelés hozzájárulhat a szekunder bronchuscarcinoma kialakulásához. Megjegyzendő azonban, hogy továbbra is a dohányzás a legfontosabb tényező annak kialakulásában [43]. A carcinoma kialakulásának valószínüsége függ az irradiáció típusától, a besugárzott tüdőterület nagyságától és az összdózistól. A kemoterápiás protokollok közül a MOPP okozta fokozott rizikóról számoltak be [44]. A jelenleg is használt modern kemoterápiás protokollok bronchuscarcinomát előidéző fokozott rizikója egyelöre pontosan nem ismert.

Ibrabim és mtsai a kis sejtes tüdőrák irradiáció okozta ötszörös rizikójáról számoltak be metaanalízisükben az egészséges populációhoz viszonyítva. A csak kemote- 


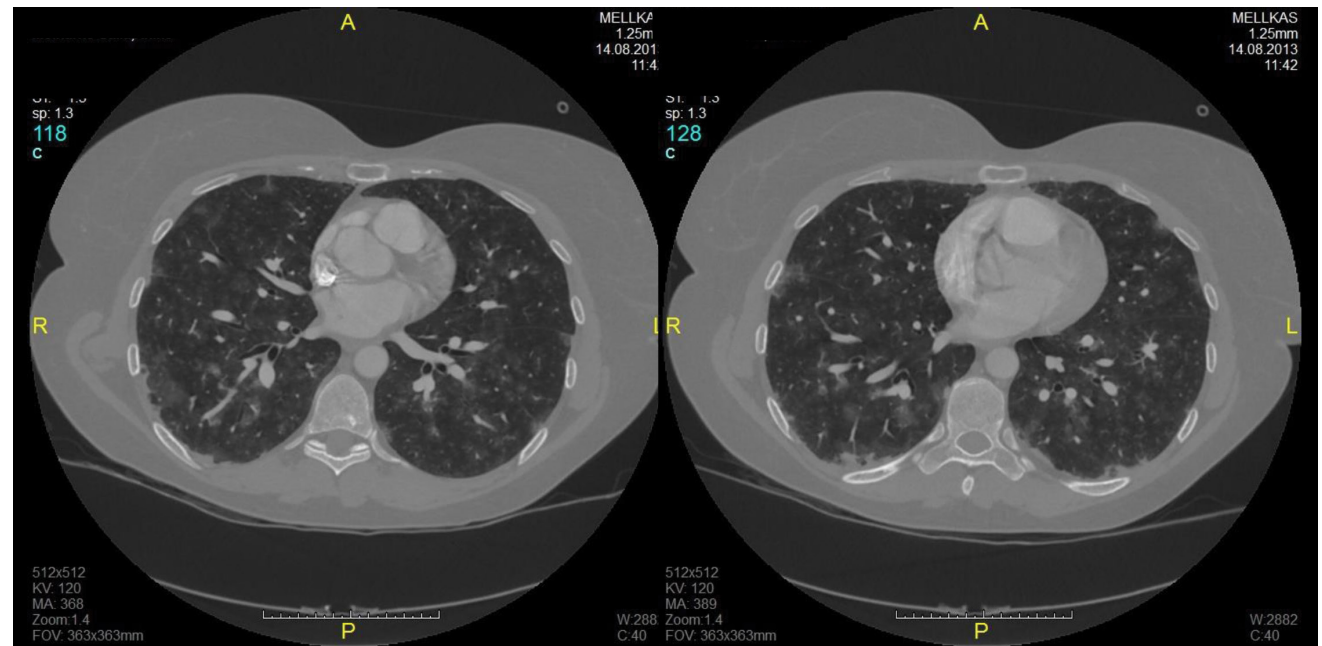

8. ábra

Akut diffúz tüdőkárosodás (ARDS) képe, amely a fiatal HL-beteg kezelésének ( 6 × COPP /ABV + mantle irradiáció) befejezése után 20 évvel annak következtében kialakult pulmonalis fibrosis és immunszupprimált állapot talaján kialakult multirezisztens nosocomialis alsó légúti infekció következménye

rápiával kezeltek jelentősen alacsonyabb, kétszeres, az alkilálószerrel is kezeltek háromszoros rizikóval számolhattak [45]. A férfi nem, az idősebb kor, az alkilálószerek használata és a dohányzás hozzájárultak a tüdőrák kialakulásához. A 45 évnél idősebb, dohányos, HL miatt kezelt betegek esetén évenkénti mellkas-CT elvégzését ajánlották, különösen a kezelés befejezése utáni 10-14. évtől, mivel tüdőrák kialakulására ekkor mutatkozott a legnagyobb esély, 15 év után már nem emelkedett szignifikánsan ennek rizikója.

Összehasonlításképpen: egy harmincas évei előtt ABVD-vel kezelt, nem dohányzó HL-beteg relatíve kis rizikóval bír szekunder bronchuscarcinoma kialakulására, míg egy több mint negyvenéves, alkilálószer-tartalmú kemoterápiát (például COPP vagy $\mathrm{COPP} / \mathrm{ABV}$ ) és mellkast is érintő irradiációban (esetleg mantle) részesülő, dohányos HL-beteg szignifikánsan nagyobb rizikóval bír [46] (9. ábra).

\section{Pulmonalis embolia}

A malignus betegségek általában, így a HL is thromboemboliás szövődményekre hajlamosít. Mindennek hátterében az emelkedettebb protrombin, VIII. faktor aktivitás és a károsodott thrombocytafunkció állhat. Egy több mint 18 ezer lymphomás beteget magába foglaló metaanalízis mégis szignifikánsan kevesebb pulmonalis emboliát talált HL-betegek esetén (4,7\%), mint egyéb nem Hodgkin-lymphomáknál. Rizikófaktort jelentett az előrehaladottabb betegség és természetesen az örökletes vagy szerzett thrombophilia jelenléte [47]. Egy másik tanulmány is hasonló adatokat talált thromboemboliás események előfordulására: 7,25\% [48]. Több pulmonalis embolia jelentkezett súlyos nemkívánatos eseményként a fázis $1 \mathrm{~A}+\mathrm{AVD}$ vs. ABVD klinikai tanulmány kísérleti karán [49]. Betegeinknél ezért nagy tumortömeg esetén rutinszerüen alkalmazunk LMWH-profilaxist.
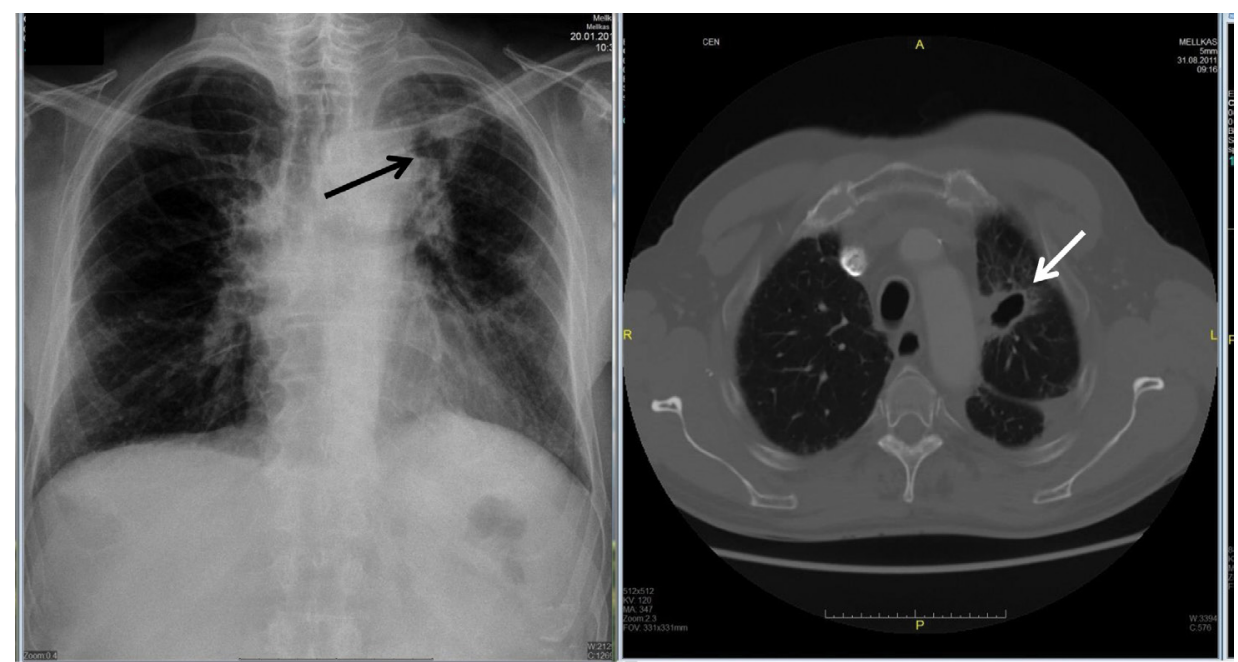

9. ábra | Dohányos HL-beteg kezelése $(8 \times$ ABVD) után 7 évvel planocellularis carcinoma igazolódott, amelyet a mellkasröntgen- és CT-képen nyíllal jelöltünk 


\section{Következtetések}

Hodgkin-lymphomás esetek 8-12\%-ában fordul elő a tüdő érintettsége. A pulmonalis manifesztáció igazolása diagnosztikai és differenciáldiagnosztikai problémát jelent, mintavételi és értékelési nehézséget okoz.

A ráterjedéses, nagy kiterjedésû folyamatok gyakran okozhatnak pleuralis folyadékot, amelynek metabolikus aktivitásának meghatározása PET/CT útján lehetséges. Amennyiben negatív esetben is gyanúnk van a folyadék aktív voltára, úgy mintavétel és citológia javasolható. A kis - metabolikusan nem karakterizálható - pulmonalis micronodulusokat nem tartjuk lymphomás érintettségnek. Mindezek felismerése és követése fontos a pontos stádiummeghatározás, rizikócsoportba sorolás és ezek alapján a megfelelő, személyreszabott kezelés pontos megválasztásában, amely alapja a gyógyulásnak.

A HL kezelése során a különböző terápiák, így döntően a bleomycin és az irradiáció, közvetlen tüdőkárosító hatása ismert. Általánosságban elmondható, hogy napjainkban törekszünk a kemoterápia minimalizálására, adott esetben célzott terápiás lehetőségekkel való helyettesítésére. A jövőben várható ezen új szerek egyre korábban való alkalmazása a kórlefolyás során. További kutatások szükségesek a pontos hatásmechanizmusok megértéséhez, hogy kiválaszthassuk azt a betegcsoportot, amelyben a leghatékonyabbnak bizonyulnak (első vonal, relapsus, fenntartó kezelés, áthidaló megoldás: „bridging”). Esetleg egymással kombinálni lehet ooket, hogy a konvencionális kemoterápiát teljesen elhagyhassuk.

A manapság használt irradiáció jóval kisebb területet érint és kisebb dózisokat is használunk, mint korábban. A terápiás lehetőségek bővülésével talán jelentősége is csökken, mindenesetre a napjainkban irradiált HL-betegek jóval kedvezőbb életminőségnek örvendenek, mint évtizedekkel korábban.

A betegek kezelése és követése során kialakuló infekciók, illetve második daganat(ok) kialakulására is számítani kell, amely(ek) felismerése és kezelése a betegek életminősége és hosszú távú túlélése, gyógyulása szempontjából kiemelkedő fontosságú.

Anyagi támogatás: A közlemény megírása anyagi támogatásban nem részesült.

Szerzői munkamegosztás: J. Á.: A kézirat megírása. Sz. K.: Közremúködés a kézirat megírásában. I. Á., M. Zs.: Javaslatot tett a kézirat szerkezetére és elfogadta a kézirat végleges formáját. A cikk végleges változatát valamennyi szerző elolvasta és jóváhagyta.

Érdekeltségek: A szerzőknek nincsenek érdekeltségeik.

\section{Irodalom}

[1] Bonadonna, G., Zucali, R., Monfardini, S., et al.: Combination chemotherapy of Hodgkin's disease with adriamycin, bleomycin, vinblastine, and imidazole carboxamide versus MOPP. Cancer, 1975, 36(1), 252-259.

[2] Gallamini, A., Hutchings, M., Rigacci, L., et al.: Early interim 2-[18F]fluoro-2-deoxy-d-glucose positron emission tomography is prognostically superior to international prognostic score in advanced-stage Hodgkin's lymphoma: a report from a joint Italian-Danish study. J. Clin. Oncol., 2007, 25(24), 3746-3752.

[3] Ramchandren, R.: Advances in the treatment of relapsed or refractory Hodgkin's lymphoma. Oncologist, 2012, 17(3), 367376.

[4] Ansell, S. M., Lesokhin, A. M., Borrello, I., et al.: PD-1 blockade with nivolumab in relapsed or refractory Hodgkin's lymphoma. N. Engl. J. Med., 2015, 372(4), 311-319.

[5] Miltényi, Z., Keresztes, K., Végh, J., et al.: What is the price of survival in Hodgkin's lymphoma? Long-term follow-up of cured patients. Hematol. Oncol., 2007, 25(4), 178-183.

[6] Simon, Z., Keresztes, K., Miltényi, Z., et al.: Our experiences with treating patients of Hodgkin's disease in the last decade. [Hodgkin-lymphomás betegeink kezelése során szerzett tapasztalatok az utóbbi évtizedben.] Orv. Hetil., 2007, 148(15), 675-682. [Hungarian]

[7] Miltenyi, Z., Magyari, F., Simon, Z., et al.: Quality of life and fatigue in Hodgkin's lymphoma patients. Tumori, 2010, 96(4), 594-600

[8] Diederich, S., Link, T. M., Zühlsdorf, H., et al.: Pulmonary manifestations of Hodgkin's disease: radiographic and CT findings. Eur. Radiol., 2001, 11(11), 2295-2305.

[9] Guermazi, A., Brice, P., de Kerviler, E. E., et al.: Extranodal Hodgkin disease: spectrum of disease. Radiographics, 2001, 21(1), 161-179.

[10] Lluch-Garcia, R., Briones-Gomez, A., Castellano, E. M., et al.: Primary pulmonary Hodgkin's lymphoma. Can. Respir. J., 2010, 17(6), el06-el08.

[11] Radin, A. I.: Primary pulmonary Hodgkin's disease. Cancer, 1990, 65(3), 550-563.

[12] Paes, F. M., Kalkanis, D. G., Sideras, P. A., et al.: FDG PET/CT of extranodal involvement in non-Hodgkin lymphoma and Hodgkin disease. Radiographics, 2010, 30(1), 269-291.

[13] Simon, Z., Jóna, A., Miltényi, Z., et al.: Diagnostic difficulties caused by a pulmonary infiltrate. [Diagnosztikai nehézséget okozó pulmonalis infiltrátum.] Orv. Hetil., 2012, 153(27), 1077-1081.

[14] Codrich, D., Monai, M., Pelizzo, G., et al.: Primary pulmonary Hodgkin's disease and tuberculosis in an 11-year-old boy: case report and review of the literature. Pediatr. Pulmonol., 2006, 41(7), 694-698.

[15] Gould, M. K., Fletcher, J., Iannettoni, M. D., et al.: Evaluation of patients with pulmonary nodules: when is it lung cancer? ACCP evidence-based clinical practice guidelines (2nd edition). Chest, 2007, 132(3 Suppl.), 108S-130S.

[16] Illés, Á., Molnár, Zs.: State of the art treatment of adult Hodgkin lymphoma. In: Lehocky, D. (ed.): Treatment of hematolohic diseases. [A felnőttkori Hodgkin-lymphoma ellátásának irányelvei. In: Lehocky, D. (szerk.): Hematológiai betegségek korszerű kezelése.] Zafír Press, Budapest, 2011, 151-164. [Hungarian]

[17] Froudarakis, M., Hatzimichael, E., Kyriazopoulou, L., et al.: Revisiting bleomycin from pathophysiology to safe clinical use. Crit. Rev. Oncol., Hematol., 2013, 87(1), 90-100. 
[18] Oken, M. M., Crooke, S. T., Elson, M. K., et al.: Pharmacokinetics of bleomycin after im administration in man. Cancer Treat. Rep., 1981, 65(5-6), 485-489.

[19] Carnevale-Schianca, F., Gallo, S., Rota-Scalabrini, D., et al.: Complete resolution of life-threatening bleomycin-induced pneumonitis after treatment with imatinib mesylate in a patient with Hodgkin's lymphoma: Hope for severe chemotherapy-induced toxicity? J. Clin. Oncol., 2011, 29(24), e691-e693.

[20] Bucbler, T., Bomanji, J., Lee, S. M.: FDG-PET in bleomycin-induced pneumonitis following ABVD chemotherapy for Hodgkin's disease - a useful tool for monitoring pulmonary toxicity and disease activity. Haematologica, 2007, 92(11), el20-e121.

[21] Morikawa, M., Demura, Y., Mizuno, S., et al.: FDG positron emission tomography imaging of drug-induced pneumonitis. Ann. Nucl. Med., 2008, 22(4), 335-338.

[22] Ansell, S. M., Connors, J. M., Park, S. I., et al.: Frontline therapy with brentuximab vedotin combined with ABVD or AVD in patients with newly diagnosed advanced stage Hodgkin lymphoma. Blood, 2012, 120(21), 798.

[23] Borchmann, P., Eichenauer, D. A., Plutschow, A., et al.: Targeted BEACOPP variants in patients with newly diagnosed advanced stage classical Hodgkin lymphoma: interim results of a randomized phase II study. Blood, 2013, 122(21), 4344.

[24] Oki, צ., Younes, A.: Current role of gemcitabine in the treatment of Hodgkin lymphoma. Leuk. Lymphoma, 2008, 49(5), 883889.

[25] Friedberg, J. W., Neuberg, D., Kim, H., et al.: Gemcitabine added to doxorubicin, bleomycin, and vinblastine for the treatment of de novo Hodgkin disease: unacceptable acute pulmonary toxicity. Cancer, 2003, 98(5), 978-982.

[26] Bredenfeld, H., Franklin, J., Nogova, L., et al.: Severe pulmonary toxicity in patients with advanced-stage Hodgkin's disease treated with a modified bleomycin, doxorubicin, cyclophosphamide, vincristine, procarbazine, prednisone, and gemcitabine (BEACOPP) regimen is probably related to the combination of gemcitabine and bleomycin: a report of the German Hodgkin's Lymphoma Study Group. J. Clin. Oncol., 2004, 22(12), 24242429.

[27] Blum, K. A., Jung, S. H., Johnson, J. L., et al.: Serious pulmonary toxicity in patients with Hodgkin's lymphoma with SGN-30, gemcitabine, vinorelbine, and liposomal doxorubicin is associated with an Fc $\{$ gamma $\}$ RIIIa- $158 \mathrm{~V} / \mathrm{F}$ polymorphism. Ann. Oncol., 2010, 21(11), 2246-2254.

[28] Alessandrino, E. P., Bernasconi, P., Colombo, A., et al.: Pulmonary toxicity following carmustine-based preparative regimens and autologous peripheral blood progenitor cell transplantation in hematological malignancies. Bone Marrow Transplant., 2000, 25(3), 309-313.

[29] Musso, M., Messina, G., Di Renzo, N., et al.: Improved outcome of patients with relapsed/refractory Hodgkin lymphoma with a new fotemustine-based high-dose chemotherapy regimen. Br. J. Haematol., 2015 Oct 12. doi: 10.1111/bjh.13803. [Epub ahead of print]

[30] Jules-Elysee, K., White, D. A.: Bleomycin-induced pulmonary toxicity. Clin. Chest Med., 1990, 11(1), 1-20.

[31] Macann, A., Bredenfeld, H., Müller, R. P., et al.: Radiotherapy does not influence the severe pulmonary toxicity observed with the administration of gemcitabine and bleomycin in patients with advanced-stage Hodgkin's lymphoma treated with the BAGCOPP regimen: a report by the German Hodgkin's Lymphoma Study Group. Int. J. Radiat. Oncol. Biol. Phys., 2008, $70(1), 161-165$.

[32] Matthews, J. H.: Pulmonary toxicity of ABVD chemotherapy and G-CSF in Hodgkin's disease: possible synergy. Lancet, 1993, 342 (8877), 988.
[33] Saxman, S. B., Nichols, C. R., Einhorn, L. H.: Pulmonary toxicity in patients with advanced-stage germ cell tumors receiving bleomycin with and without granulocyte colony stimulating factor. Chest, 1997, 111(3), 657-660.

[34] Koh, E. S., Sun, A., Tran, T. H., et al.: Clinical dose-volume histogram analysis in predicting radiation pneumonitis in Hodgkin's lymphoma. Int. J. Radiat. Oncol. Biol. Phys., 2006, 66(1), 223-228.

[35] Tarbell, N. J., Mauch, P., Hellmann, S.: Pulmonary complications of Hodgkin's disease treatment: Radiation pneumonitis, fibrosis and the effect of cytotoxic drugs. In: Lacher, M. J., Redman, J. R. (eds.): Hodgkin's disease: the consequences of survival. Lea \& Febiger, Philadelphia, London, 1990, 296-305.

[36] Ng, A. K., Li, S., Neuberg, D., et al.: A prospective study of pulmonary function in Hodgkin's lymphoma patients. Ann. Oncol., 2008, 19(10), 1754-1758.

[37] Vakkalanka, B., Link, B. K.: Neutropenia and neutropenic complications in ABVD chemotherapy for Hodgkin lymphoma. Adv. Hematol., 2011, 2011, 656013.

[38] Kalin, M., Kristinsson, S. Y., Cherif, H., et al.: Fatal pneumocystis jiroveci pneumonia in ABVD-treated Hodgkin lymphoma patients. Ann. Hematol., 2010, 89(5), 523-525.

[39] Riabukbina, I. E., Larionova, V. B., Demina, E. A., et al.: Infectious complications in patients with Hodgkin's lymphoma of unfavourable prognosis. Antibiot. Khimioter., 2007, 52(1-2), 28-38.

[40] Sinkó, J., Csomor, J., Nikolova, R., et al.: Invasive fungal disease in allogeneic hematopoietic stem cell transplant recipients: an autopsy-driven survey. Transpl. Infect. Dis., 2008, 10(2), 106-109.

[41] Rabitsch, W., Staudinger, T., Brugger, S. A., et al.: Successful management of adult respiratory distress syndrome (ARDS) after high-dose chemotherapy and peripheral blood progenitor cell rescue by non-invasive ventilatory support. Bone Marrow Transplant., 1998, 21(10), 1067-1069.

[42] Baxi, S. S., Matasar, M. J.: State-of-the-art issues in Hodgkin's lymphoma survivorship. Curr. Oncol. Rep., 2010, 12(6), 366373.

[43] Travis, L. B., Gospodarowicz, M., Curtis, R. E., et al.: Lung cancer following chemotherapy and radiotherapy for Hodgkin's disease. J. Natl. Cancer Inst., 2002, 94(3), 182-192.

[44] Hoppe, R. T., Mauch, P. T., Armitage, J. O., et al.: Hodgkin lymphoma. 2nd ed. Wolters Kluwer Health/Lippincott Williams \& Wilkins, Philadelphia, 2007.

[45] Ibrabim, E. M., Kazkaz, G. A., Abouelkbair, K. M., et al.: Increased risk of second lung cancer in Hodgkin's lymphoma survivors: a meta-analysis. Lung, 2013, 191(1), 117-134.

[46] Hodgson, D. C., van Leeuwen, F. E.: Second malignancy risk after treatment of Hodgkin lymphoma. In: Engert, A., Horning, S. J. (eds.): Hodgkin lymphoma. Springer, Berlin, 2010.

[47] Caruso, V., Di Castelnuovo, A., Meschengieser, S., et al.: Thrombotic complications in adult patients with lymphoma: a metaanalysis of 29 independent cohorts including 18018 patients and 1149 events. Blood, 2010, 115(26), 5322-5328.

[48] Mohren, M., Markmann, I., Jentsch-Ullrich, K., et al.: Increased risk of thromboembolism in patients with malignant lymphoma: a single-centre analysis. Br. J. Cancer, 2005, 92(8), 1349-1351.

[49] Younes, A., Connors, J. M., Park, S. I., et al.: Brentuximab vedotin combined with ABVD or AVD for patients with newly diagnosed Hodgkin's lymphoma: a phase 1, open-label, dose-escalation study. Lancet Oncol., 2013, 14(13), 1348-1356.

(Jóna Ádám dr.,

Debrecen, Nagyerdei krt. 98., 4032 e-mail: jona.adam1@gmail.com) 